\title{
Article
}

\section{The Reaction of Cellulolytic and Potentially Cellulolytic Spore-Forming Bacteria to Various Types of Crop Management and Farmyard Manure Fertilization in Bulk Soil}

\author{
Jakub Dobrzyński ${ }^{1}\left(\mathbb{D}\right.$, Paweł Stanisław Wierzchowski ${ }^{1, *}$, Wojciech Stępień ${ }^{2}$ and Ewa Beata Górska ${ }^{3}$ (D) \\ 1 Institute of Technology and Life Sciences, Falenty Al. Hrabska 3, 05-090 Raszyn, Poland; \\ j.dobrzynski@itp.edu.pl \\ 2 Department of Agricultural Chemistry, Institute of Agriculture, Warsaw University of Life Sciences SGGW, \\ Nowoursynowska 166, 02-787 Warsaw, Poland; wojciech_stepien@sggw.edu.pl \\ 3 Department of Biochemistry and Microbiology, Institute of Biology, Warsaw University of Life Sciences SGGW, \\ Nowoursynowska 166, 02-787 Warsaw, Poland; ewa_gorska@sggw.edu.pl \\ * Correspondence: s.wierzchowski@itp.edu.pl
}

Citation: Dobrzyński, J.; Wierzchowski, P.S.; Stępień, W.; Górska, E.B. The Reaction of Cellulolytic and Potentially Cellulolytic Spore-Forming Bacteria to Various Types of Crop Management and Farmyard Manure Fertilization in Bulk Soil. Agronomy 2021, 11, 772. https://doi.org/ 10.3390/agronomy11040772

Academic Editors: Agnieszka Kuźniar, Jolanta Jaroszuk-Ściseł, Magdalena Frąc and Agnieszka Wolińska

Received: 26 March 2021 Accepted: 13 April 2021 Published: 15 April 2021

Publisher's Note: MDPI stays neutral with regard to jurisdictional claims in published maps and institutional affiliations.

Copyright: (c) 2021 by the authors. Licensee MDPI, Basel, Switzerland. This article is an open access article distributed under the terms and conditions of the Creative Commons Attribution (CC BY) license (https:// creativecommons.org/licenses/by/ $4.0 /)$.

\begin{abstract}
The ecology of cellulolytic bacteria in bulk soil is still relatively unknown. There is still only a handful of papers on the abundance and diversity of this group of bacteria. Our study aimed to determine the impact of various crop management systems and farmyard manure (FYM) fertilization on the abundance of cellulolytic and potentially cellulolytic spore-forming bacteria (SCB). The study site was a nearly 100-year-old fertilization experiment, one of the oldest still active field trials in Europe. The highest contents of total carbon (TC) and total nitrogen (TN) were recorded in both five-year rotations. The abundances of SCB and potential SCB were evaluated using classical microbiological methods, the most probable number (MPN), and 16S rRNA Illumina MiSeq sequencing. The highest MPN of SCB was recorded in soil with arbitrary rotation without legumes (ARP) fertilized with FYM (382 colony-forming units (CFU) $\mathrm{mL}^{-1}$ ). As a result of the bioinformatic analysis, the highest values of the Shannon-Wiener index and the largest number of operational taxonomic units (OTUs) were found in ARP-FYM, while the lowest in ARP treatment without FYM fertilization. In all treatments, those dominant at the order level were: Brevibacillales (13.1-43.4\%), Paenibacillales (5.3-36.9\%), Bacillales (4.0-0.9\%). Brevibacillaceae (13.1-43.4\%), Paenibacillaceae (8.2-36.9\%), and Clostridiaceae (5.4-11.9\%) dominated at the family level in all tested samples. Aneurinibacillaceae and Hungateiclostridiaceae families increased their overall share in FYM fertilization treatments. The results of our research show that the impact of crop management types on SCB was negligible while the actual factor shaping SCB community was the use of FYM fertilization.
\end{abstract}

Keywords: crop management; next generation sequencing; soil microbiome; fertilization; cellulolytic spore-forming bacteria

\section{Introduction}

In recent decades, we have observed a rapid increase in agricultural production. The pursuit of maximum crop yielding leads to changes in the chemical, physical, and biological properties of soil [1,2]. This phenomenon is caused by the use of various agrotechnical practices, including the use of crop protection agents, long-term mineral fertilization, and long-term cropping in monoculture [3,4]. Continuous cropping can lead to decreased yields, an increase in the number of fungal phytopathogens, and a biological imbalance in soil $[5,6]$. To a large extent, microorganisms are responsible for maintaining biological balance and determining the direction of biochemical processes occurring in soil [7]. Therefore, knowledge about the impact of agrotechnical practices on the abundance and biodiversity of microorganisms in soil is crucial.

Cellulose is the most common biopolymer in soil. Thus, an important group of microorganisms involved in the circulation of elements in the soil are cellulose-degrading 
microorganisms [8]. Soil properties such as $\mathrm{pH}$, moisture, and soil organic matter content influence microbial cellulose degradation. This process requires a complex of enzymes belonging to the class of O-glycoside hydrolases, including endo- $\beta$-1,4-glucanases (EC 3.2.1.4), exoglucanases, syn. 1,4- $\beta$-glucan cellobiohydrolase (EC 3.2.1.91), and cellobiase, syn. $\beta$-glucosidase (EC 3.2.1.21) [9,10]. In soil, cellulolytic enzymes are primarily produced by fungi and bacteria. Cellulolytic microorganisms include relatively anaerobic, sporeforming bacteria (SCB). This group includes bacteria of the phylum Firmicutes, among others from the Bacilliaceae, Paenibacilliaceae, Clostridriaceae families which numerously occur in different types of bulk soil [11,12]. Moreover, relatively anaerobic, spore-forming bacteria can be used as plant growth promoters. SCB may promote plant growth through direct and indirect mechanisms. Direct mechanisms include the secretion of phytohormones, e.g., auxins (e.g., indoleacetic acid-IAA) and gibberellins, fixation of atmospheric nitrogen (nitrogenase production), and solubilization of nutrients such as phosphates. Indirect mechanisms of plant growth promotion based on protection against phytopathogens largely depend on enzymes degrading fungal cell walls, e.g., chitinases and glucanases [13-17].

The ecology of cellulolytic bacteria in arable soils is still relatively poorly understood. Thus, the study aimed to evaluate the impact of monoculture and rotation systems as well as farmyard manure fertilization on the abundance of potential cellulolytic and cellulolytic spore-forming bacteria in soil from nearly a century-old fertilization experiment. It is worth mentioning that currently there are only a few other similar experiments in Europe, for instance in Rothamsted (Great Britain) conducted since 1843, and in Halle (Germany) conducted since 1894. Such a long-term monoculture, crop rotation, and farmyard manure fertilization field trial allowed for a unique assessment of the bacterial community of tested microorganisms.

\section{Materials and Methods}

\subsection{Site Characteristics}

The research was carried out in in the fields of the Institute of Agriculture, University of Life Sciences in Skierniewice, Poland (51 $57^{\prime} 54.8^{\prime \prime}$ N 20 $\left.09^{\prime} 27.4^{\prime \prime} \mathrm{E}\right)$. The experiment was established in 1922 on loamy sand textured Luvisol and from the beginning to the present, it is conducted in triplicate. On plots without liming $\mathrm{pH}$ was approximately 4.5. The average annual temperature for the period 1921-2017 was $8.0^{\circ} \mathrm{C}$, and the annual precipitation was $530 \mathrm{~mm}$. The size of a single plot was $4 \mathrm{~m} \times 9 \mathrm{~m}$. The buffer zone between plots was $2 \mathrm{~m}$ wide. The presented study included seven crop rotation and soil management treatments with or without farmyard manure (FYM) fertilization (Table 1).

Table 1. Experimental treatments.

\begin{tabular}{|c|c|c|c|}
\hline Abbr. & Crop Management & Crops & FYM Fertilization \\
\hline ARP & $\begin{array}{l}\text { Arbitrary rotation without legumes } \\
\text { (since 1923) }\end{array}$ & Potato *-winter wheat- spring barley & No \\
\hline ARP-FYM & $\begin{array}{l}\text { Arbitrary rotation without legumes } \\
\text { (since } 1992 \text { with FYM) }\end{array}$ & Potato *-winter wheat-spring barley & Yes $\left(30 \mathrm{tha}^{-1}\right)$ \\
\hline LRL & Rotation with legumes (since 1924) & Lupine *-spring triticale-barley & No \\
\hline FRR & Five-year rotation (since 1924) & $\begin{array}{l}\text { Lupine-winter wheat-rye } \\
\text { *-potato-barley }\end{array}$ & Yes $\left(30 \mathrm{tha}^{-1}\right)$ \\
\hline FRP & Five-year rotation (since 1924) & $\begin{array}{l}\text { Lupine-winter wheat-rye-potato } \\
\text { *-barley }\end{array}$ & Yes $\left(30 \mathrm{tha}^{-1}\right)$ \\
\hline MP & Monoculture (since 1923) & Potato & Yes $\left(20 \mathrm{tha}^{-1}\right)$ \\
\hline MR & Monoculture (since 1923) & Rye & Yes $\left(20 \mathrm{tha}^{-1}\right)$ \\
\hline
\end{tabular}

* Crop present during sampling. 
Sample-source plots were limed since 1976 with doses $1.6 \mathrm{t} \mathrm{CaO}$ ha every 4 years on arbitrary rotation without legumes (ARP), ARP with farmyard manure (FYM), rotation with legumes (LRL) and every 5 years on potato monoculture (MP), rye monoculture (MR), rye five-year rotation (FRR), and potato five-year rotation (FRP).

\subsection{Sampling and Chemical Analysis}

Samples of bulk soil were taken by a sampler probe in July 2017. Soil samples per experimental treatment were collected from a depth of 0-20 cm from three separate plots. Each plot sample was a composite sample made out of soil collected from three random points. Soil for chemical analysis was then air-dried, ground, and passed through a $2 \mathrm{~mm}$ sieve. The following chemical parameters were determined in soil samples: total carbon (TC) [18] and total nitrogen (TN) by the direct method [19], pH in $1 \mathrm{M} \mathrm{KCl}$ [20]. Soil for most probable number (MPN) analysis was passed through a sterile $2 \mathrm{~mm}$ sieve and stored at $4{ }^{\circ} \mathrm{C}$ (MPN analysis lasted 2 days).

\subsection{Microbiological Analyses}

Most probable number of SCB was determined using the dilution method with three replicates. Ten grams of soil were suspended in $100 \mathrm{~mL}$ of sterilized water and then tenfold serial dilutions were prepared. Next, one $\mathrm{mL}$ of dilutions $10^{-1}, 10^{-2}, 10^{-3}, 10^{-4}, 10^{-5}$ was added to Park medium $\left(\left(\mathrm{NH}_{4}\right)_{2} \mathrm{SO}_{4}-0.5 \mathrm{~g} ; \mathrm{KH}_{2} \mathrm{PO}_{4}-1.0 \mathrm{~g} ; \mathrm{KCl}-0.5 \mathrm{~g} ; \mathrm{MgSO}_{4}-0.2 \mathrm{~g}\right.$; $\mathrm{CaCl}_{2}-0.1 \mathrm{~g}$, with the addition of $0.5 \mathrm{~cm} \times 8 \mathrm{~cm}$ filter papers). To ensure that only sporeforming bacteria are present in the samples, cultures were pasteurized for $15 \mathrm{~min}$ at $85^{\circ} \mathrm{C}$, then incubated for 21 days at $28^{\circ} \mathrm{C}$. Filter paper degradation was evaluated macroscopically, and later the readout was carried out using McCrady's statistical tables [21], and expressed as colony forming units (CFU) per $\mathrm{ml}$.

\subsection{DNA Extraction and $16 S$ rRNA Sequencing}

The genetic material for sequencing analysis came from 21-day cultures of SCB. 7 representative samples were made by merging 6 repeated culture samples per treatment $(5 \mathrm{~mL}$ each): three repetitions of cultured samples from a dilution of $10^{-1}(0.1 \mathrm{~g}$ soil) and three from $10^{-2}$ ( $0.01 \mathrm{~g}$ soil). Then the representative samples were shaken at $200 \mathrm{rpm}$ for $30 \mathrm{~min}$, $2 \mathrm{~mL}$ aliquots were frozen in liquid nitrogen and stored at $-80^{\circ} \mathrm{C}$.

DNA isolation was carried out with a method based on the Genomic Mini AX Bacteria + kit (A\&A Biotechnology, Gdynia, Poland). After isolation, the DNA was further purified using an Anti-Inhibitor kit (A\&A Biotechnology, Gdynia, Poland).

Analysis of the genes encoding $16 \mathrm{~S}$ rRNA was carried out based on the hypervariable V4 region of the 16S rRNA gene. Specific 515F (5'-GTGCCAGCMGCCGCGGTAA-3') and 806R (5'-GGACTACHVHHHTWTCTAA-3') primer sequences were used to amplify the selected region and prepare the library. The polymerase chain reaction (PCR) was carried out using the NEBNext ${ }^{\circledR}$ High-Fidelity 2X PCR Master Mix. Sequencing took place on the MiSeq sequencer, in paired-end (PE) technology, $2 \times 250 \mathrm{nt}$, using Illumina v2. Sequencing data was deposited in the National Center for Biotechnology Information (NCBI) Sequence Read Archive under BioProject accession PRJNA665141.

The 16S rRNA gene sequence reads were processed with mothur [22]. Paired-end reads were merged and assembled using the make.contigs command. Pairs shorter than $290 \mathrm{bp}$, longer than $300 \mathrm{bp}$, or with an average Phred score quality below 25 were discarded. Chimaeras were removed using the vsearch algorithm. The final reads were clustered into operational taxonomic units (OTUs) using dist.seqs and cluster commands (opticlust algorithm) with a 0.03 distance cut off. A taxonomic identity was attributed to each OTU via the SILVA 134 rRNA database [23] using an 80\% homogeneity cut off. Rarefaction curves along with data used for figure generation are available in the Supplementary Materials (Figure S1, Table S1). 


\subsection{Statistical Analysis and Data Visualisation}

Statistical analysis and data visualization was undertaken using $\mathrm{R}$ 3.5.3 statistical programming language [24]. The Shannon-Wiener diversity index was calculated using mothur's built-in functionality. Bray-Curtis dissimilarities between OTU compositions of individual samples were calculated and plotted for principal coordinate analysis (PCoA) using the phyloseq package [25]. One-way analysis of variance (ANOVA) was used for the analysis of soil chemical parameters and MPN $(n=3)$ among seven treatments. Differences between treatments were tested using the Tukey-Kramer honest significant difference (HSD) test at $\alpha=0.05$ [26]. Variance homogeneity was examined using Levene's test. The Wilk-Shapiro normality statistic was calculated to determine if residual values conformed to a normal distribution.

\section{Results and Discussion}

\subsection{Soil Parameters and Most Probable Number (MPN)}

In most treatments, the $\mathrm{pH}$ values were similar, small differences between ARP-FYM and FRR (Table 2) may have been caused by the use of liming. C:N ratio was at a similar level. The exception being soil from the LRL treatment, where significantly lower C:N ratio (9.70) was observed. This result may be explained by the presence of lupine in the year of study, thanks to symbiosis with atmospheric nitrogen-fixing bacteria the TN content in bulk soil increased. The highest values of TC were recorded in FRR and FRP soils, respectively $0.7 \%$ and $0.68 \%$. Similar patterns were observed for total nitrogen values, the highest TN contents were recorded in FRR $(654 \mathrm{mg} / \mathrm{kg})$ and FRP $(648 \mathrm{mg} / \mathrm{kg})$ soils, along with slightly lower values in LRL soil (532 mg/ $\mathrm{kg}$ ), compared to monoculture, higher TN contents were also observed in other rotations. Long-term organic residue accumulation may have been responsible for changes in TN concentration. These results are consistent with the previous study of Stępien and Kobiałka [27] conducted at the same experimental station. The authors showed higher TC and TN contents in crop rotation soils compared to monoculture soils. Moreover, Adamiak and Adamiak [28] showed slightly lower TC content in five-year rotation soil (rye in the study year) compared to rye monoculture soil after 18 years of FYM fertilization. Values obtained were also similar to those in the study of Congreves, et al. [29], where authors found higher soil organic carbon (SOC) and $\mathrm{TN}$ content in corn-soybean-wheat rotation soil compared to corn continuous cropping soil at the 11-year-old long-term fertilization experiment located in Canada. In contrast, Kaiser et al. [30] obtained lower SOC content in rye-potato rotation soil in comparison with long-term rye monoculture soil-long-term trials in Halle (Germany). The authors explained this phenomenon by crop rotation-specific soil organic matter mineralization.

Table 2. Soil chemical properties and most probable number (MPN) of cellulolytic spore-forming bacteria (SCB).

\begin{tabular}{cccccc}
\hline Treatment & pH & TC (\%) & TN (mg kg $\left.{ }^{-1}\right)$ & C:N Ratio & MPN (CFU mL \\
\hline ARP & $6.10 \pm 0.04 \mathrm{ab}$ & $0.47 \pm 0.15 \mathrm{ab}$ & $427.00 \pm 20.00 \mathrm{c}$ & $10.80 \pm 0.40 \mathrm{ab}$ & $45.00 \pm 12.16 \mathrm{~d}$ \\
\hline ARP-FYM & $6.00 \pm 0.13 \mathrm{~b}$ & $0.53 \pm 0.10 \mathrm{ab}$ & $479.00 \pm 34.00 \mathrm{bc}$ & $11.00 \pm 0.90 \mathrm{ab}$ & $382.00 \pm 19.67 \mathrm{a}$ \\
\hline LRL & $6.10 \pm 0.10 \mathrm{ab}$ & $0.56 \pm 0.13 \mathrm{ab}$ & $532.00 \pm 16.00 \mathrm{~b}$ & $9.70 \pm 0.32 \mathrm{~b}$ & $25.00 \pm 6.80 \mathrm{~d}$ \\
\hline MP & $6.10 \pm 0.09 \mathrm{ab}$ & $0.37 \pm 0.10 \mathrm{ab}$ & $324.00 \pm 20.00 \mathrm{~d}$ & $11.40 \pm 0.70 \mathrm{a}$ & $30.00 \pm 6.11 \mathrm{~d}$ \\
\hline MR & $6.20 \pm 0.11 \mathrm{ab}$ & $0.36 \pm 0.13 \mathrm{~b}$ & $329.00 \pm 32.00 \mathrm{~d}$ & $10.90 \pm 0.60 \mathrm{ab}$ & $50.00 \pm 10.00 \mathrm{~d}$ \\
\hline FRR & $6.30 \pm 0.06 \mathrm{a}$ & $0.70 \pm 0.11 \mathrm{a}$ & $654.00 \pm 30.00 \mathrm{a}$ & $10.70 \pm 0.63 \mathrm{ab}$ & $293.00 \pm 17.08 \mathrm{~b}$ \\
\hline FRP & $6.20 \pm 0.09 \mathrm{ab}$ & $0.68 \pm 0.12 \mathrm{ab}$ & $648.00 \pm 28.00 \mathrm{a}$ & $10.50 \pm 0.40 \mathrm{ab}$ & $249.00 \pm 17.90 \mathrm{c}$ \\
\hline Prob $>$ F & 0.038 & 0.020 & $<0.001$ & 0.089 & $<0.001$ \\
\hline
\end{tabular}

Different letters behind the mean values and SD $(n=3)$ indicate significant differences (Tukey-Kramer HSD test, $\alpha<0.05)$. 
Compared to monoculture treatments $\mathrm{MP}\left(\mathrm{CFU} \mathrm{mL}{ }^{-1}\right)$ and $\mathrm{MR}\left(50 \mathrm{CFU} \mathrm{mL}{ }^{-1}\right)$, significantly higher MPN of SCB was recorded in FRR $\left(293\right.$ CFU mL $\left.{ }^{-1}\right)$ and FRP $\left(249\right.$ CFU mL $\left.\mathrm{mL}^{-1}\right)$ crop rotations. Obtained results may be explained by the impact of greater amounts of crop residues which induced spore-forming cellulolytic bacteria growth in crop rotation treatments. Available literature provides scant information on the impact of crop management and FYM fertilization on the MPN of SCB. Gregorutti and Caviglia [31] found no connections between the crop residues and the MPN of cellulolytic bacteria in the field experiment conducted in Argentina. Moreover, Pankhurst et al. [32] showed a lack of significant differences between the activity of cellulose-decomposing microorganisms in crop rotation soil (wheat-sown pasture) and continuous wheat soil in long-term experiments in South Australia. The authors explained their results by low winter rainfall and the dry soil conditions. The discrepancy between our results and these studies could possibly be explained by differences in soil properties and climate conditions.

In addition, significantly higher numbers of SCB in arbitrary rotation without legumes with FYM fertilization (382 CFU mL ${ }^{-1}$ ) compared to ARP without FYM fertilization $\left(45 \mathrm{CFU} \mathrm{mL} \mathrm{mL}^{-1}\right.$ ) were noted. Most likely, the long-term FYM fertilization caused an increase in the amount of $\mathrm{N}$ and $\mathrm{C}$ in soil, which led to an increase in the most probable number of tested bacteria. Similar patterns were observed by Górska et al. [33].

\section{2. $16 S$ rRNA Sequencing}

Analysis of 16S rRNA genes was carried out on cultures of cellulolytic SCB. Hence, our bacterial group is referred to as cellulolytic spore-forming bacteria and potentially cellulolytic spore-forming bacteria. The central dogma of microbiology claims that $90 \%$ of microorganisms found in all environments of our globe are non-cultivable [34]. Development of next-generation sequencing (NGS) has contributed to the hypothesis that this value may be overstated, as confirmed by some researchers. Van Insberghe et al. [35] have isolated 1264 isolates (from 8 different culture media) from forest soils that have previously been sequenced. Comparative analysis showed that the isolates constituted about $22 \%$ of OTUs obtained from bioinformatic analysis of $16 \mathrm{~S}$ rRNA genes from this soil. Moreover, Bai et al. [36] created a comprehensive collection of more than 2000 isolates derived from Arabidopsis root extract and sequenced the 16S rRNA genes of these isolates. Then, compared the 16S rRNA of the Arabidopsis root extract and found out that about $60 \%$ of OTUs coincide with the 16S rRNA gene sequences of the studied isolates. Referring to this data, the analysis of 16S rRNA genes was carried out in bacterial cultures. This type of analysis gave an insight into this particular physiological group of microorganisms which are SCB and potentially cellulolytic SCB.

A total of $608,04216 \mathrm{~S}$ bacterial raw sequences were obtained from 7 samples. After quality filtering, a total of 407,526 sequences were obtained (53,096 unique), with an average of 58,218 sequences per sample (Table 3). A total of 5029 unique OTUs were formed after binning with $97 \%$ similarity rate.

Table 3. Reads after processing, operational taxonomic unit (OTU) numbers, Shannon biodiversity index, and coverage.

\begin{tabular}{ccccc}
\hline Treatment & Sequences & OTUs & Shannon & Coverage \\
\hline ARP & 43,800 & 804 & 2.73 & $98.80 \%$ \\
ARP-FYM & 59,097 & 1288 & 3.52 & $98.50 \%$ \\
LRL & 81,093 & 1089 & 2.91 & $99.10 \%$ \\
FRR & 62,032 & 1205 & 2.95 & $98.70 \%$ \\
FRP & 40,610 & 1150 & 3.25 & $98.10 \%$ \\
MP & 53,464 & 1270 & 3.30 & $98.40 \%$ \\
MR & 67,430 & 975 & 3.51 & $99.10 \%$ \\
\hline
\end{tabular}

As a result of sequencing SCB cultures, in all samples about $100 \%$ of OTUs were assigned to the phylum Firmicutes. Firmicutes is the dominant bacterial phylum in arable 
soils. Its abundance in the soil bacterial communities ranges from $3 \%$ to $18 \%$ depending on agrotechnical practices $[37,38]$. Shannon index and OTU results are partly consistent with results obtained by the classical microbiology analysis. Most OTUs were observed in ARP-FYM treatment (1288), and slightly fewer OTUs were found in MP treatment (1270). While the lowest OTU numbers (less than 1000) were noted in MR and ARP treatments, this observation is in line with lower MPN values obtained for these treatments. The Shannon index was partly consistent with OTU numbers. The highest Shannon values were recorded in ARP-FYM and MR treatment, 3.52 and 3.51, respectively, while the lowest was observed in ARP treatment (2.73). Opinions about the impact of crop management systems on OTU numbers and diversity indexes of whole soil bacterial communities are divergent. For instance, Yin et. al. [39] observed the decrease in richness and the Shannon index in rotation soil (wheat and soybeans compared to wheat monoculture). Similar patterns were detected by Mayer et al. [40]. Soman et al. [41] did not report differences in bacterial diversity and OTU numbers in soil from two different rotations (two-year corn and soybean, and three-year corn-oat-alfalfa)—-long-term trails at the Morrow Plots (Urbana, Illinois, United States). Venter et al. [42] based on the meta-analysis of richness and biodiversity of bacteria in soil from different crop managements, documented that higher values of bacterial richness and biodiversity occurred in soils from crop rotation. In our work based on the phylum Firmicutes, we did not notice major differences in these parameters. Zhao et al. [38] recorded significantly increased abundances of the phylum Firmicutes in bacterial communities in soil from 15- and 22-year-old cucumber monoculture soil compared to the cucumber planted for one season. Previously, Zhao et al. [3] detected the same patterns in coffee monoculture. However, these authors did not explain their findings in detail. Overall, the phylum Firmicutes was more abundant in crop rotation soils compared to monoculture soils [43-46]. This occurrence was explained by the impact of crop residues and decaying roots accumulating over time, and more generally by soil health resulting from crop rotation. The discrepancies between the studies are not clear and may be caused by other factors such as micronutrient content or soil electrical conductivity (EC). Thus, further research is needed to explain this phenomenon, e.g., determining the correlation between more detailed soil physicochemical properties, and the abundance of the phylum Firmicutes in treatments. For instance, previous studies investigating the impact of cotton monoculture ( 20 years) on soil bacterial communities showed positive correlation between the abundance of phylum Firmicutes and soil EC [43]. Finally, differences between studies may have also been caused by the heterogeneity of agricultural practices, as previously noted by Soman et al. [41].

The PCoA analysis showed that FYM fertilization in comparison to crop management was a stronger factor modulating bacterial communities in analysed treatments. Figure 1 shows significant distances between bacterial communities from treatments with or without FYM fertilization.

PCoA results were consistent with higher values of OTUs, Shannon index and MPN of tested bacteria in ARP-FYM treatment. Cellulose present in FYM straw may have been responsible for stimulating the increase in SCB and potentially SCB abundance. Additionally, most members of Firmicutes have generally been described as copiotrophs which are fast-growing microorganisms that prefer environments rich in organic matter [47]. Francioli et al. [48] observed relatively more Firmicutes in farmyard manure fertilized soils in a long-term fertilization experiment. Similarly, Hartmann et al. [49] observed an increased percentage of Firmicutes in long-term FYM fertilization when compared to mineral fertilization. This phenomenon was additionally confirmed by a study investigating the impact of different cropping practices on bulk soil and rhizosphere microbiomes [50]. Moreover, the beneficial effect of FYM on richness and biodiversity of whole soil bacterial communities was recorded several times [51-53]. 


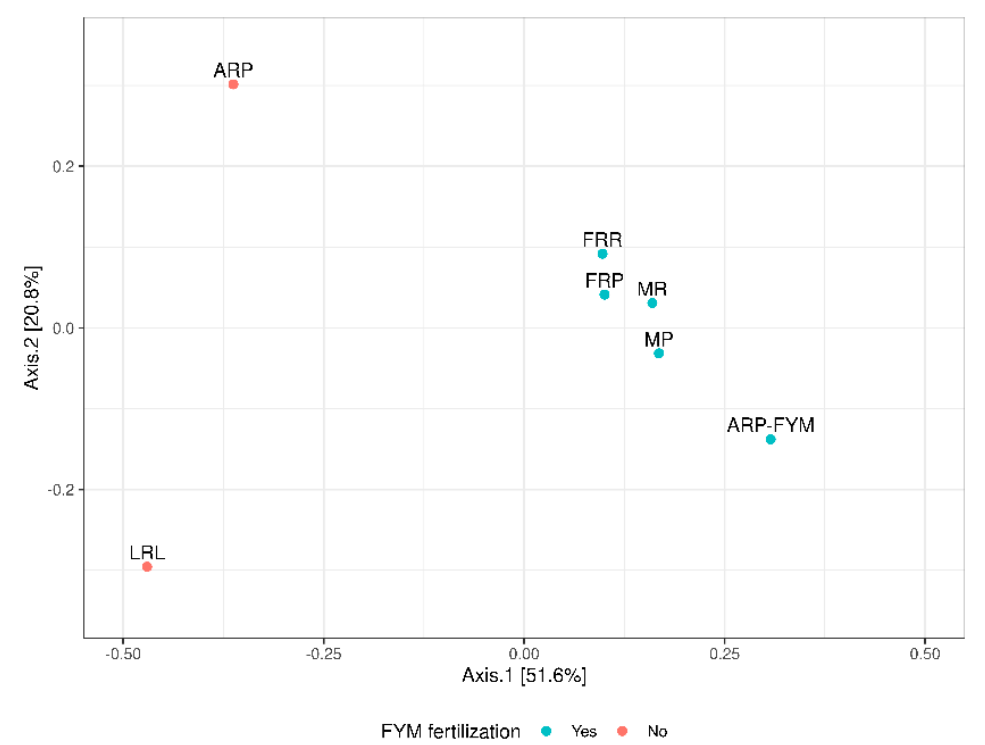

Figure 1. Principal coordinate analysis (PCoA) of OTU compositions between different samples.

Eleven bacterial orders were identified in the treatments, the dominants at order level (Figure 2) were Brevibacillales (13.1-23.4\%), Paenibacillales (5.3-36.9\%), Bacillales (4.0-30.9\%). The most abundant order Brevibacillales was recorded in ARP soil, where this order accounted for nearly $50 \%$ of all covered taxons. Moreover, a large abundance of Brevibacillales was observed in FRR (23.6\%) and FRP (22.7\%) treatments. The abundance of order Paenibacillales was quite varied in the treatments, high OTU numbers belonging to this order were recorded in LRL $(36.9 \%)$ and ARP $(22.8 \%)$ treatments. The highest abundance of Bacillales was observed in LRL treatment (30.9\%). The percentage values of Aneurinibacillales were similar in most treatments and ranged from 16.7 to $20.1 \%$, exceptions were LRL and ARP treatments (below 2\%). Higher values were also obtained for Clostridia_or (3.0-21.7\%) and Clostridiales (5.6-11.3\%) orders.

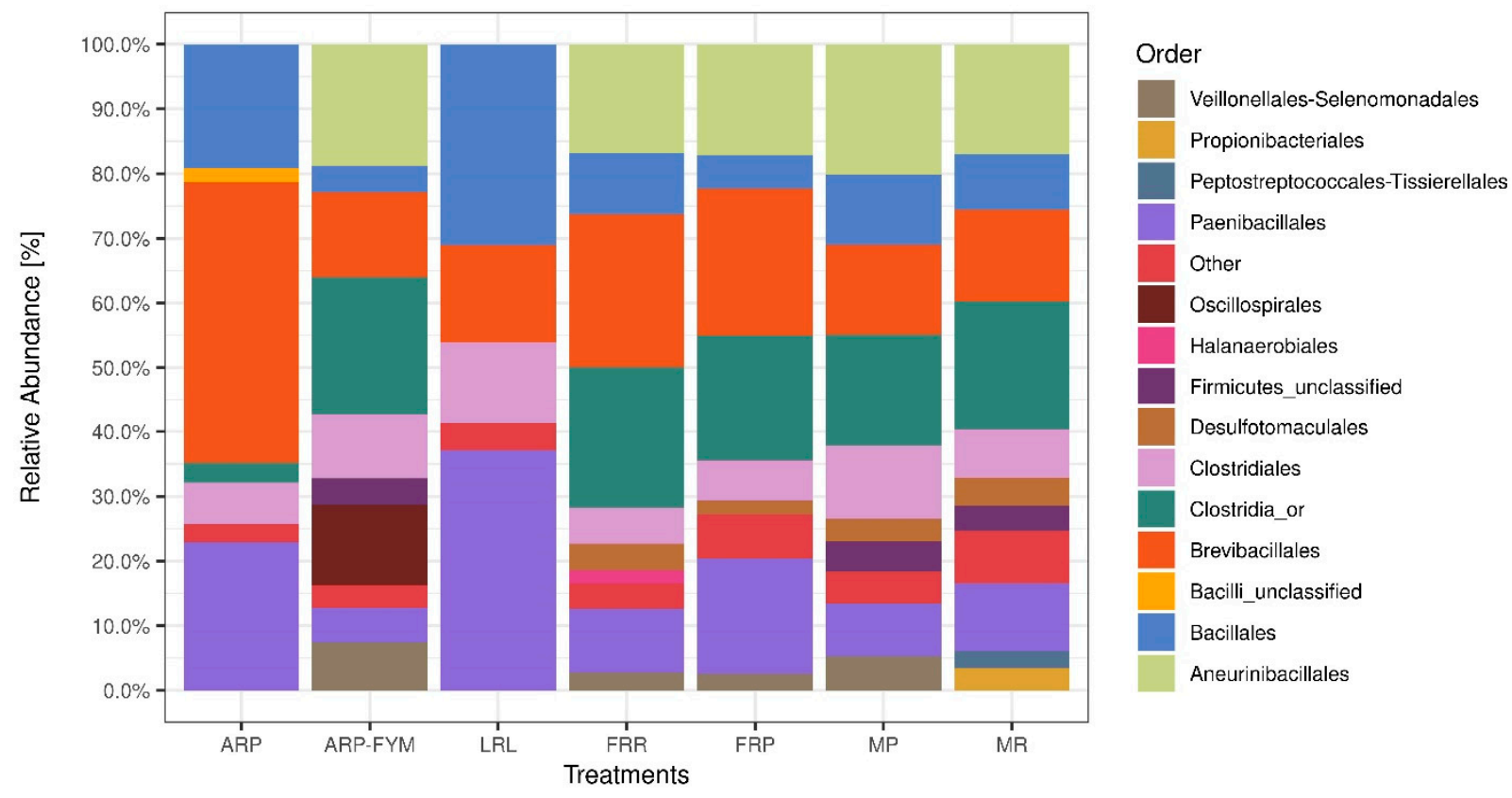

Figure 2. Bacterial abundances at the order level. ARP—arbitrary rotation without legumes, ARP-FYM-arbitrary rotation without legumes fertilized with farmyard manure, LRL—rotation with legumes, FRR—rye five-field rotation, FRP—potato five-field rotation, $\mathrm{MP}$ - potato monoculture, MR-rye monoculture. Taxons below $2 \%$ abundancy and single observation are represented by the "Other" category in the figure. 
The studied bacterial community patterns at the family level were similar to those recorded for orders (Figure 3). Brevibacillaceae (13.1-43.4\%), Paenibacillaceae (8.2-36.9\%), and Clostridiaceae (5.4-11.9\%) dominated at the family level in all treatments. Currently there are no data available in other studies that describe possible changes in communities of cellulolytic and potentially cellulolytic SCB at the order and family level depending on crop management and FYM fertilization. Higher abundance of the family Paenibacillaceae in LRL and ARP treatments, in comparison to all other treatments, may be connected with the lack of FYM fertilization in those treatments. So far, bacteria belonging to the family Paenibacillaceae have been isolated from a variety of soil environments [54,55]. The Paenibacillaceae family is one of the best-described Firmicutes families. A large number of Paenibacillus strains are capable of producing direct plant growth promoters, including phytohormones, phosphate solubilization, and nitrogen fixation [56,57]. In addition, bacteria belonging to the genus Paenibacillus can help control phytopathogens by triggering induced systemic resistance (ISR) or by producing a variety of biological compounds including lipopeptides with antibiotic properties $[54,58,59]$. Thus, the presence of these family members may help improve plant and soil health.

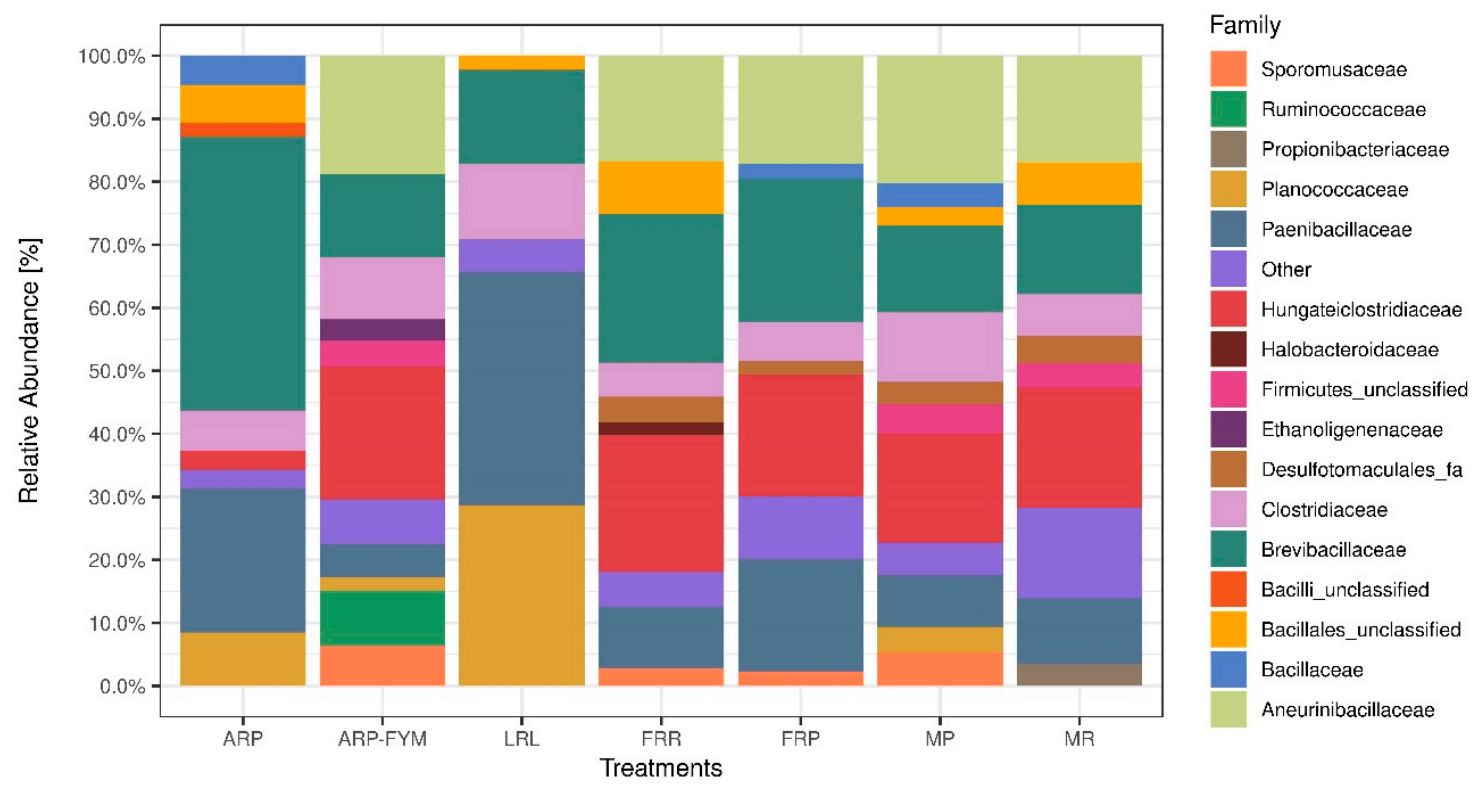

Figure 3. Bacterial abundances at the family level. ARP—arbitrary rotation without legumes, ARP-FYM-arbitrary rotation without legumes fertilized with farmyard manure, LRL—rotation with legumes, FRR—rye five-field rotation, FRP—potato five-field rotation, $\mathrm{MP}$ - potato monoculture, MR—rye monoculture. Taxons below $2 \%$ abundancy and single observation are represented by the "Other" category in the figure.

Results obtained at the family level also confirmed lower abundance of Aneurinibacillales in the ARP and LRL bacterial communities. The large abundance of the family Aneurinibacillaceae in most treatments may be explained by FYM fertilization, but the reason for this observation seems unclear and its detailed explanation requires further research. Bacteria belonging to the family Aneurinibacillaceae have been isolated from a variety of environments. Several strains of Aneurinibacillaceae were capable of promoting plant growth. Chauhan et al. [60] detected the production of nitrogenases, IAA, and the ability to solubilize phosphates in a new strain Aneurinibacillus aneurinilyticus CKMV1. The authors also detected antifungal activity against a few phytopathogens, e.g., Fusarium oxysporum, Alternaria sp., and Rhizoctonia solani. Alenezi et al. [61] also showed the potential of biocontrol against plant diseases in the strain Aneurinibacillus migulanus that produced a new gramicidin. Antifungal activity of Aneurinibacillus migulanus was also detected by Schuster and Schmitt [62]. Additionally, three nitrogenases genes were found in the genome of Aneurinibacillus terranovensis [63]. Thus, the presence of bacteria 
belonging to Aneurinibacillaceae may have a positive impact on soil health in treatments with FYM fertilization.

The family Planococcaceae belonging to the order Bacillales was a definite dominant in crop rotation with legumes-LRL treatment $(28.5 \%)$. This observation may be explained by the impact of decaying legume roots. The presence of Planococcaceae members in legumes' rhizosphere was also described by other authors [64,65].

Additionally, Figure 3 shows some information about anaerobic bacteria. The family Hungateiclostridiaceae abundance in LRL treatment was less than $2 \%$, while the abundance of Hungateiclostridiaceae in ARP reached 3\%. The relatively low abundance of this taxon, in comparison to other treatments, may be connected with no FYM fertilization in these treatments. However, this hypothesis is difficult to explain since the abundance of the related anaerobic family of bacteria Clostridaceae was relatively high in all tested treatments. Hungateiclostridiaceae is a novel family of anaerobic bacteria belonging to the phylum Firmicutes. So far, researchers have isolated members of this family from various environments and described a few strains: Defluviitalea raffinosedens, Hungateiclostridium mesophilum, and Hungateiclostridium thermocellum. These strains were able to produce cellulolytic and xylanolytic enzymes [66-68].

\section{Conclusions}

In summary, results obtained in this study answered some questions about the impact of long-term crop management and FYM fertilization on the studied bacterial group. Biodiversity and OTU numbers of SCB and potentially SCB showed that crop rotation and long-term monoculture had a relatively negligible impact on the analyzed bacterial communities. The differences between ARP-FYM and ARP indicated that farmyard manure was a more potent factor in shaping SCB communities, most likely due to straw present in FYM. A crucial difference in the community structures was an increased abundance in the Aneurinibacillaceae and Hungateiclostridiaceae families in FYM fertilization treatments. Thanks to their plant growth promoting capabilities, members of these families can have a positive impact on arable soil health. However, further research is needed to determine the exact mechanisms that increase their abundance in FYM fertilization treatments.

Supplementary Materials: The following are available online at https:/ /www.mdpi.com/article/10 .3390/agronomy11040772/s1, Table S1: Data used for Figures 2 and 3, Figure S1: Rarefaction curves.

Author Contributions: Conceptualization, J.D., W.S. and E.B.G.; Data curation, P.S.W.; Formal analysis, E.B.G.; Funding acquisition, E.B.G.; Methodology, J.D. and E.B.G.; Project administration, W.S.; Resources, W.S.; Software, P.S.W.; Supervision, E.B.G.; Validation, E.B.G.; Visualization, P.S.W.; Writing—original draft, J.D.; Writing—review and editing, P.S.W. All authors have read and agreed to the published version of the manuscript.

Funding: This research was funded by the Polish Ministry of Science and Higher Education, grant number SPUB 505-30-012600-L00280-99 titled “Decision 8762E-385SPUB201”.

Institutional Review Board Statement: Not applicable.

Informed Consent Statement: Not applicable.

Data Availability Statement: Sequencing data available under the following accession number: PRJNA665141 (https:/ / www.ncbi.nlm.nih.gov/bioproject/PRJNA665141/ (accessed on 14 April 2021)).

Conflicts of Interest: The authors declare no conflict of interest.

\section{References}

1. Burzyńska, I. Monitoring of Selected Fertilizer Nutrients in Surface Waters and Soils of Agricultural Land in the River Valley in Central Poland. J. Water Land Dev. 2019, 43, 41-48. [CrossRef]

2. Dinka, M.O.; Dawit, M. Spatial Variability and Dynamics of Soil PH, Soil Organic Carbon and Matter Content: The Case of the Wonji Shoa Sugarcane Plantation. J. Water Land Dev. 2019, 42, 59-66. [CrossRef]

3. Zhao, Q.; Xiong, W.; Xing, Y.; Sun, Y.; Lin, X.; Dong, Y. Long-Term Coffee Monoculture Alters Soil Chemical Properties and Microbial Communities. Sci. Rep. 2018, 8, 6116. [CrossRef] [PubMed] 
4. Kiełbasa, B.; Pietrzak, S.; Ulén, B.; Drangert, J.-O.; Tonderski, K. Sustainable Agriculture: The Study on Farmers' Perception and Practices Regarding Nutrient Management and Limiting Losses. J. Water Land Dev. 2018, 36, 67-75. [CrossRef]

5. Liu, X.; Li, Y.; Han, B.; Zhang, Q.; Zhou, K.; Zhang, X.; Hashemi, M. Yield Response of Continuous Soybean to One-Season Crop Disturbance in a Previous Continuous Soybean Field in Northeast China. Field Crops Res. 2012, 138, 52-56. [CrossRef]

6. Xiong, W.; Zhao, Q.; Zhao, J.; Xun, W.; Li, R.; Zhang, R.; Wu, H.; Shen, Q. Different Continuous Cropping Spans Significantly Affect Microbial Community Membership and Structure in a Vanilla-Grown Soil as Revealed by Deep Pyrosequencing. Microb. Ecol. 2015, 70, 209-218. [CrossRef]

7. Barrios, E. Soil Biota, Ecosystem Services and Land Productivity. Ecol. Econ. 2007, 64, 269-285. [CrossRef]

8. Dimarogona, M.; Topakas, E.; Christakopoulos, P. Cellulose Degradation by Oxidative Enzymes. Comput. Struct. Biotechnol. J. 2012, 2, e201209015. [CrossRef]

9. Maki, M.; Leung, K.T.; Qin, W. The Prospects of Cellulase-Producing Bacteria for the Bioconversion of Lignocellulosic Biomass. Int. J. Biol. Sci. 2009, 500-516. [CrossRef]

10. Khalili, B.; Nourbakhsh, F.; Nili, N.; Khademi, H.; Sharifnabi, B. Diversity of Soil Cellulase Isoenzymes Is Associated with Soil Cellulase Kinetic and Thermodynamic Parameters. Soil Biol. Biochem. 2011, 43, 1639-1648. [CrossRef]

11. Islam, M.T.; Rahman, M.M.; Pandey, P.; Jha, C.K.; Aeron, A. (Eds.) Bacilli and Agrobiotechnology; Bacilli in Climate Resilient Agriculture and Bioprospecting; Springer International Publishing: Cham, Switzerland, 2016; ISBN 978-3-319-44408-6.

12. Vilain, S.; Luo, Y.; Hildreth, M.B.; Brözel, V.S. Analysis of the Life Cycle of the Soil Saprophyte Bacillus Cereus in Liquid Soil Extract and in Soil. AEM 2006, 72, 4970-4977. [CrossRef] [PubMed]

13. Zafar-ul-Hye, M.; Danish, S.; Abbas, M.; Ahmad, M.; Munir, T.M. ACC Deaminase Producing PGPR Bacillus Amyloliquefaciens and Agrobacterium Fabrum along with Biochar Improve Wheat Productivity under Drought Stress. Agronomy 2019, 9, 343. [CrossRef]

14. Akinrinlola, R.J.; Yuen, G.Y.; Drijber, R.A.; Adesemoye, A.O. Evaluation of Bacillus Strains for Plant Growth Promotion and Predictability of Efficacy by In Vitro Physiological Traits. Int. J. Microbiol. 2018, 2018, 5686874. [CrossRef]

15. Aloo, B.N.; Makumba, B.A.; Mbega, E.R. The Potential of Bacilli Rhizobacteria for Sustainable Crop Production and Environmental Sustainability. Microbiol. Res. 2019, 219, 26-39. [CrossRef]

16. Maheshwari, D.K. (Ed.) Plant Growth and Health Promoting Bacteria; Microbiology Monographs; Springer: Berlin/Heidelberg, Germany, 2011; Volume 18, ISBN 978-3-642-13611-5.

17. Jo, H.; Tagele, S.B.; Pham, H.Q.; Kim, M.-C.; Choi, S.-D.; Kim, M.-J.; Park, Y.-J.; Ibal, J.C.; Park, G.-S.; Shin, J.-H. Response of Soil Bacterial Community and Pepper Plant Growth to Application of Bacillus Thuringiensis KNU-07. Agronomy 2020, 10, 551. [CrossRef]

18. ISO. Soil Quality-Determination of Organic and Total Carbon after Dry Combustion (Elementary Analysis); ISO 10694: 2002; International Organization for Standardization (ISO): Geneva, Switzerland, 2002.

19. ISO. Soil Quality-Determination of Total Nitrogen-Modified Kjeldahl Method; ISO 11261:2002; International Organization for Standardization (ISO): Geneva, Switzerland, 2002.

20. ISO. Determination of PH; 10390: 1997; International Organization for Standardization (ISO): Geneva, Switzerland, 1997.

21. McCrady, M.H. The Numerical Interpretation of Fermentation-Tube Results. J. Infect. Dis. 1915, 17, 183-212. [CrossRef]

22. Schloss, P.D.; Westcott, S.L.; Ryabin, T.; Hall, J.R.; Hartmann, M.; Hollister, E.B.; Lesniewski, R.A.; Oakley, B.B.; Parks, D.H.; Robinson, C.J.; et al. Introducing Mothur: Open-Source, Platform-Independent, Community-Supported Software for Describing and Comparing Microbial Communities. Appl. Environ. Microbiol. 2009, 75, 7537-7541. [CrossRef]

23. Quast, C.; Pruesse, E.; Yilmaz, P.; Gerken, J.; Schweer, T.; Yarza, P.; Peplies, J.; Glöckner, F.O. The SILVA Ribosomal RNA Gene Database Project: Improved Data Processing and Web-Based Tools. Nucleic. Acids Res. 2013, 41, D590-D596. [CrossRef]

24. R Core Team. R: A Language and Environment for Statistical Computing; R Foundation for Statistical Computing: Vienna, Austria, 2020.

25. McMurdie, P.J.; Holmes, S. Phyloseq: An R Package for Reproducible Interactive Analysis and Graphics of Microbiome Census Data. PLoS ONE 2013, 8, e61217. [CrossRef]

26. de Mendiburu, F.; Yaseen, M. Agricolae: Statistical Procedures for Agricultural Research; National Engineering University: Lima, Peru, 2020.

27. Stępień, W.; Kobiałka, M. Effect of Long-Term Organic and Mineral Fertilisation on Selected Physico-Chemical Soil Properties in Rye Monoculture and Five-Year Crop Rotation. Soil Sci. Annu. 2019, 70, 34-38. [CrossRef]

28. Adamiak, E.; Adamiak, J. Changes of the Chosen Chemical Properties of Soil as a Result of Long-Term Cereal Cultivation in Crop Rotation and Monoculture. Acta Sci. Pol. Agric. 2015, 14, 3-10.

29. Congreves, K.A.; Hooker, D.C.; Hayes, A.; Verhallen, E.A.; van Eerd, L.L. Interaction of Long-Term Nitrogen Fertilizer Application, Crop Rotation, and Tillage System on Soil Carbon and Nitrogen Dynamics. Plant Soil 2017, 410, 113-127. [CrossRef]

30. Kaiser, M.; Ellerbrock, R.H.; Gerke, H.H. Long-Term Effects of Crop Rotation and Fertilization on Soil Organic Matter Composition. Eur. J. Soil Sci. 2007, 58, 1460-1470. [CrossRef]

31. Gregorutti, V.C.; Caviglia, O.P. Impact of Crop Aerial and Root Biomass Inputs on Soil Nitrifiers and Cellulolytic Microorganisms. Soil Tillage Res. 2019, 191, 85-97. [CrossRef]

32. Pankhurst, C.E.; Hawke, B.G.; McDonald, H.J.; Kirkby, C.A.; Buckerfield, J.C.; Michelsen, P.; O’Brien, K.A.; Gupta, V.; Doube, B.M. Evaluation of Soil Biological Properties as Potential Bioindicators of Soil Health. Aust. J. Exp. Agric. 1995, 35, 1015-1028. [CrossRef] 
33. Górska, E.B.; Russel, S.; Łabętowicz, J. Effect of long-term fertilization on the occurence of aerobic, mesophilic, cellulolytic spore-forming bacteria in soil. Zesz. Probl. Postęp. Nauk Rol. 1999, 465, 517-526.

34. Hugenholtz, P.; Pace, N. Identifying Microbial Diversity in the Natural Environment: A Molecular Phylogenetic Approach. Trends Biotechnol. 1996, 14, 190-197. [CrossRef]

35. VanInsberghe, D.; Hartmann, M.; Stewart, G.R.; Mohn, W.W. Isolation of a Substantial Proportion of Forest Soil Bacterial Communities Detected via Pyrotag Sequencing. Appl. Environ. Microbiol. 2013, 79, 2096-2098. [CrossRef] [PubMed]

36. Bai, Y.; Müller, D.B.; Srinivas, G.; Garrido-Oter, R.; Potthoff, E.; Rott, M.; Dombrowski, N.; Münch, P.C.; Spaepen, S.; RemusEmsermann, M.; et al. Functional Overlap of the Arabidopsis Leaf and Root Microbiota. Nature 2015, 528, 364-369. [CrossRef]

37. Hartmann, M.; Widmer, F. Community Structure Analyses Are More Sensitive to Differences in Soil Bacterial Communities than Anonymous Diversity Indices. Appl. Environ. Microbiol. 2006, 72, 7804-7812. [CrossRef] [PubMed]

38. Zhao, Y.; Mao, X.; Zhang, M.; Yang, W.; Di, H.J.; Ma, L.; Liu, W.; Li, B. Response of Soil Microbial Communities to Continuously Mono-Cropped Cucumber under Greenhouse Conditions in a Calcareous Soil of North China. J. Soils Sediments 2020, 20, 2446-2459. [CrossRef]

39. Yin, C.; Jones, K.L.; Peterson, D.E.; Garrett, K.A.; Hulbert, S.H.; Paulitz, T.C. Members of Soil Bacterial Communities Sensitive to Tillage and Crop Rotation. Soil Biol. Biochem. 2010, 42, 2111-2118. [CrossRef]

40. Mayer, Z.; Sasvári, Z.; Szentpéteri, V.; Pethőné Rétháti, B.; Vajna, B.; Posta, K. Effect of Long-Term Cropping Systems on the Diversity of the Soil Bacterial Communities. Agronomy 2019, 9, 878. [CrossRef]

41. Soman, C.; Li, D.; Wander, M.M.; Kent, A.D. Long-Term Fertilizer and Crop-Rotation Treatments Differentially Affect Soil Bacterial Community Structure. Plant Soil 2017, 413, 145-159. [CrossRef]

42. Venter, Z.S.; Jacobs, K.; Hawkins, H.-J. The Impact of Crop Rotation on Soil Microbial Diversity: A Meta-Analysis. Pedobiologia 2016, 59, 215-223. [CrossRef]

43. Yang, L.; Tan, L.; Zhang, F.; Gale, W.J.; Cheng, Z.; Sang, W. Duration of Continuous Cropping with Straw Return Affects the Composition and Structure of Soil Bacterial Communities in Cotton Fields. Can. J. Microbiol. 2018, 64, 167-181. [CrossRef]

44. Li, H.; Wang, J.; Liu, Q.; Zhou, Z.; Chen, F.; Xiang, D. Effects of Consecutive Monoculture of Sweet Potato on Soil Bacterial Community as Determined by Pyrosequencing. J. Basic. Microbiol. 2019, 59, 181-191. [CrossRef]

45. Li, N.; Gao, D.; Zhou, X.; Chen, S.; Li, C.; Wu, F. Intercropping with Potato-Onion Enhanced the Soil Microbial Diversity of Tomato. Microorganisms 2020, 8, 834. [CrossRef]

46. Zhu, S.; Wang, Y.; Xu, X.; Liu, T.; Wu, D.; Zheng, X.; Tang, S.; Dai, Q. Potential Use of High-Throughput Sequencing of Soil Microbial Communities for Estimating the Adverse Effects of Continuous Cropping on Ramie (Boehmeria Nivea L. Gaud). PLoS ONE 2018, 13, e0197095. [CrossRef]

47. Lienhard, P.; Terrat, S.; Prévost-Bouré, N.C.; Nowak, V.; Régnier, T.; Sayphoummie, S.; Panyasiri, K.; Tivet, F.; Mathieu, O.; Levêque, J.; et al. Pyrosequencing Evidences the Impact of Cropping on Soil Bacterial and Fungal Diversity in Laos Tropical Grassland. Agron. Sustain. Dev. 2014, 34, 525-533. [CrossRef]

48. Francioli, D.; Schulz, E.; Lentendu, G.; Wubet, T.; Buscot, F.; Reitz, T. Mineral vs. Organic Amendments: Microbial Community Structure, Activity and Abundance of Agriculturally Relevant Microbes Are Driven by Long-Term Fertilization Strategies. Front. Microbiol. 2016, 7, 1446. [CrossRef]

49. Hartmann, M.; Frey, B.; Mayer, J.; Mäder, P.; Widmer, F. Distinct Soil Microbial Diversity under Long-Term Organic and Conventional Farming. ISME J. 2015, 9, 1177-1194. [CrossRef]

50. Hartman, K.; van der Heijden, M.G.A.; Wittwer, R.A.; Banerjee, S.; Walser, J.-C.; Schlaeppi, K. Cropping Practices Manipulate Abundance Patterns of Root and Soil Microbiome Members Paving the Way to Smart Farming. Microbiome 2018, 6, 14. [CrossRef]

51. Das, S.; Jeong, S.T.; Das, S.; Kim, P.J. Composted Cattle Manure Increases Microbial Activity and Soil Fertility More Than Composted Swine Manure in a Submerged Rice Paddy. Front. Microbiol. 2017, 8, 1702. [CrossRef]

52. Zhen, Z.; Liu, H.; Wang, N.; Guo, L.; Meng, J.; Ding, N.; Wu, G.; Jiang, G. Effects of Manure Compost Application on Soil Microbial Community Diversity and Soil Microenvironments in a Temperate Cropland in China. PLoS ONE 2014, 9, e108555. [CrossRef]

53. Legrand, F.; Picot, A.; Cobo-Díaz, J.F.; Carof, M.; Chen, W.; Le Floch, G. Effect of Tillage and Static Abiotic Soil Properties on Microbial Diversity. Appl. Soil Ecol. 2018, 132, 135-145. [CrossRef]

54. Grady, E.N.; MacDonald, J.; Liu, L.; Richman, A.; Yuan, Z.-C. Current Knowledge and Perspectives of Paenibacillus: A Review. Microb. Cell Fact. 2016, 15, 203. [CrossRef] [PubMed]

55. Huq, M.A. Paenibacillus Anseongense Sp. Nov. a Silver Nanoparticle Producing Bacterium Isolated from Rhizospheric Soil. Curr. Microbiol. 2020, 77, 2023-2030. [CrossRef]

56. Liu, X.; Li, Q.; Li, Y.; Guan, G.; Chen, S. Paenibacillus Strains with Nitrogen Fixation and Multiple Beneficial Properties for Promoting Plant Growth. PeerJ 2019, 7, e7445. [CrossRef]

57. Brito, L.F.; López, M.G.; Straube, L.; Passaglia, L.M.P.; Wendisch, V.F. Inorganic Phosphate Solubilization by Rhizosphere Bacterium Paenibacillus Sonchi: Gene Expression and Physiological Functions. Front. Microbiol. 2020, 11, 588605. [CrossRef]

58. Naing, K.W.; Anees, M.; Kim, S.J.; Nam, Y.; Kim, Y.C.; Kim, K.Y. Characterization of Antifungal Activity of Paenibacillus Ehimensis KWN38 against Soilborne Phytopathogenic Fungi Belonging to Various Taxonomic Groups. Ann. Microbiol. 2014, 64, 55-63. [CrossRef] 
59. Nasran, H.S.; Mohd Yusof, H.; Halim, M.; Abdul Rahman, N. Optimization of Protective Agents for The Freeze-Drying of Paenibacillus Polymyxa Kp10 as a Potential Biofungicide. Molecules 2020, 25, 2618. [CrossRef] [PubMed]

60. Chauhan, A.; Guleria, S.; Balgir, P.P.; Walia, A.; Mahajan, R.; Mehta, P.; Shirkot, C.K. Tricalcium Phosphate Solubilization and Nitrogen Fixation by Newly Isolated Aneurinibacillus Aneurinilyticus CKMV1 from Rhizosphere of Valeriana Jatamansi and Its Growth Promotional Effect. Braz. J. Microbiol. 2017, 48, 294-304. [CrossRef]

61. Alenezi, F.N.; Rekik, I.; Chenari Bouket, A.; Luptakova, L.; Weitz, H.J.; Rateb, M.E.; Jaspars, M.; Woodward, S.; Belbahri, L. Increased Biological Activity of Aneurinibacillus Migulanus Strains Correlates with the Production of New Gramicidin Secondary Metabolites. Front. Microbiol. 2017, 8. [CrossRef]

62. Schuster, C.; Schmitt, A. Efficacy of a Bacterial Preparation of Aneurinibacillus Migulanus against Downy Mildew of Cucumber (Pseudoperonospora Cubensis). Eur. J. Plant Pathol. 2018, 151, 439-450. [CrossRef]

63. Kamli, M.R.; Alzahrani, N.A.Y.; Hajrah, N.H.; Sabir, J.S.M.; Malik, A. Genome-Driven Discovery of Enzymes with Industrial Implications from the Genus Aneurinibacillus. Microorganisms 2021, 9, 499. [CrossRef]

64. Kumar, R.; Chandra, R. Influence of PGPR and PSB on Rhizobium Leguminosarum Bv. Viciae Strain Competition and Symbiotic Performance in Lentil. World J. Agric. Res. 2008, 4, 297-301.

65. Yu, X.; Kang, X.; Li, Y.; Cui, Y.; Tu, W.; Shen, T.; Yan, M.; Gu, Y.; Zou, L.; Ma, M.; et al. Rhizobia Population Was Favoured during in Situ Phytoremediation of Vanadium-Titanium Magnetite Mine Tailings Dam Using Pongamia Pinnata. Environ. Pollut. 2019, 255, 113167. [CrossRef]

66. Zhang, X.; Tu, B.; Dai, L.; Lawson, P.A.; Zheng, Z.; Liu, L.-Y.; Deng, Y.; Zhang, H.; Cheng, L. Petroclostridium Xylanilyticum Gen. Nov., Sp. Nov., a Xylan-Degrading Bacterium Isolated from an Oilfield, and Reclassification of Clostridial Cluster III Members into Four Novel Genera in a New Hungateiclostridiaceae Fam. Nov. Int. J. Syst. Evol. 2018, 68, 3197-3211. [CrossRef]

67. Rettenmaier, R.; Gerbaulet, M.; Liebl, W.; Zverlov, V.V. Hungateiclostridium Mesophilum Sp. Nov., a Mesophilic, Cellulolytic and Spore-Forming Bacterium Isolated from a Biogas Fermenter Fed with Maize Silage. Int. J. Syst. Evol. 2019, 69, 3567-3573. [CrossRef]

68. Rettenmaier, R.; Schneider, M.; Munk, B.; Lebuhn, M.; Jünemann, S.; Sczyrba, A.; Maus, I.; Zverlov, V.; Liebl, W. Importance of Defluviitalea Raffinosedens for Hydrolytic Biomass Degradation in Co-Culture with Hungateiclostridium Thermocellum. Microorganisms 2020, 8, 915. [CrossRef] 